\title{
TOWARDS A UNIFIED ANALYSIS OF THREE CROSS-LINGUISTICALLY CORRELATED TELIC CONSTRUCTIONS IN ROMANIAN
}

\author{
Imola-Ágnes Farkas*
}

\begin{abstract}
Recent approaches to the theory of aspectuality assume that there is a conceptual similarity and cross-linguistic correlation between the (un)availability of goal-of-motion, strong resultative and aspectual cognate object constructions. This paper, examining Romanian data, brings further evidence in favour of the parallel between these three telic constructions and supports the tight correlation between them. It shows that although, at first glance, this verb-framed language shows patterns that seem to argue against the above correlation and especially against the unavailability of these structures, they prove to be only apparent counterexamples to it. Moreover, without questioning the typological classification of Romanian as a verb-framed language or the validity of the cross-linguistic correlation between these constructions, it reveals that a more detailed analysis of aspectual cognate object constructions in Romanian requires a different and more careful approach, which also takes into consideration the source of the diachronic data.
\end{abstract}

Keywords: goal-of-motion structure, strong resultative construction, aspectual cognate object construction, cross-linguistic correlation, verb-framed language, Romanian.

\section{Introduction}

Several analyses of diverse syntactic data (or data at the interfaces with syntax) describe them as being counterexamples in one way or another, in the sense that they are exceptional within the context of otherwise robust patterns in a particular language or language group, or singular within cross-linguistic generalizations or the predictions of a certain theory, hence they provide evidence against that particular theory. Such analyses need to answer questions related to how such counterexamples should analytically be approached, how to decide when a counterexample is a true exception or only an apparent counterexample, or how to indicate that the theory or the cross-linguistic generalization is not on the right track and requires revision.

In the present paper $^{1}$ I take a close look at the validity of the cross-linguistic correlation between three telic constructions (i.e. goal-of-motion, strong resultative and aspectual cognate object constructions), where their parallel compositional semantics and aspectual behaviour constitute an argument for their unified grammatical analysis. In a nutshell, the advocates of the unified view (cf., for instance, Talmy 1972, 1975, 1985, 1991, 2000; Tenny 1994; Goldberg 1995; Levin \& Rappaport Hovav 1995; Snyder 2001; Beck \& Snyder 2001; Mateu 2002, 2012; Mateu \& Rigau 2002; Horrocks \& Stavrou 2003, 2006, 2010; Zubizarreta \& Oh 2007; Real Puigdollers 2008; Acedo-Matellán 2010 or Farkas 2013) propose that there exists such a close grammatical relationship between these - and especially the first two, more intensively-studied - constructions (and also

\footnotetext{
* "Babeş-Bolyai” University, Faculty of Letters, imola.farkas@ubbcluj.ro.

${ }^{1}$ I would like to thank the two anonymous reviewers of Bucharest Working Papers in Linguistics (BWPL) along with the participants of the $22^{\text {nd }}$ Annual International Conference of the English Department (University of Bucharest/online, 2021) for their insightful comments and suggestions on this article. All errors are my own.
}

Bucharest Working Papers in Linguistics XXIII, 1, 33-60, e-ISSN 2392-8093, ISSN-L 2069-9239 DOI: 10.31178/BWPL.23.1.2 
some other verbal structures) that if the syntax of a language permits one of them, it also freely permits the other two and, conversely, if the syntax of a language precludes the formation of one of them, it also precludes the formation of the other two. ${ }^{2}$ In more formal terms, recent macro-parametric approaches to cross-linguistic variation in the expression of these - and, again, especially the first two - telic constructions assume that there is a particular parameter that distinguishes one language group from another in allowing or disallowing them to combine an atelic verb with a telicity-marking element (a goal PP, an AP result predicate or an aspectual cognate object) and thus derive a telic VP.

The claims made in this paper are theoretically relevant as they focus on Romanian, which, as a verb-framed Romance language (Talmy 1985, 1991, 2000), is expected to disallow - or at least severely restrict - all three telic constructions. The present study shows that, broadly speaking, macro-parametric approaches do capture the patterns found in this language, but it is only through micro-parametric approaches and language-specific considerations that we can capture and explain the full range of these constructions both synchronically and diachronically. More specifically, despite all appearances, modern Romanian lacks both goal-of-motion and strong resultative constructions. In addition, and, as expected, so-called prototypical unergative verbs and cognate objects are subject to severe co-occurrence restrictions, hence aspectual cognate constructions are also severely restricted. But what is puzzling is the striking contrast between modern and Old Romanian (1521-1780) as far as the availability of these latter constructions is concerned, which are unproductive in the former but (very) productive in the latter stage of the language, hence they seem to challenge the verb-framed status of Old Romanian. The question thus arises as to whether Old Romanian more generally exhibits satellite-framed behaviour, which would automatically imply the availability of both goal-of-motion and strong resultative constructions. This approach would get theoretical support from the earliest stages of some Romance languages such as Old/Middle French or Old Catalan, in which residues of the satellite-framed system are indeed traceable and which are hence considered not verb-framed but so-called weak satellite-framed languages (see Acedo-Matellán's 2016 finer-grained distinction between languages with respect to how literal or metaphorical motion is expressed). ${ }^{3}$ But the motion and result constructions found in the Old Romanian texts fully conform to the classification of this stage of the language as a canonical verb-framed language. Therefore, I reject the claim that Old Romanian is a weak satellite-framed language and the alternative solution that I offer in this paper is that the availability of the aspectual

\footnotetext{
${ }^{2}$ The advocates of the non-unified view (cf. Son \& Svenonius 2008; Son 2009) claim that there is a less clear grammatical relationship between - especially the first two of - these constructions as the grammatical correlation between them is subtler than assumed (for instance, Korean lacks goal-of-motion structures but has strong resultatives). As these macro-parametric approaches do not capture the full range of cross-linguistic variation, they argue that micro-parametric perspectives need to be taken into account.

${ }^{3}$ A weak satellite-framed language does not feature satellite-framed constructions based on adjectival predicates (i.e. complex AP resultative constructions) but it can realize PathP as an element morphologically different from $v$. More precisely, such a language allows PP resultatives only if they are headed by a prefixed verb. The generalization formulated in Acedo-Matellán (2016) is that complex result constructions are always prefixed in such a language and the hypothesis put forward here is that the prefixation requirement explains the non-existence of AP resultatives (see Acedo-Matellán 2016: 159).
} 
cognate constructions found in the texts of this period of the language should be explained by the fact that they are taken over literally from the original Slavonic and Greek/Hebrew documents, and reflect the translator's great fidelity to the source text (see also Nicula Paraschiv \& Niculescu 2016). Consequently, without questioning the typological classification of Romanian as a verb-framed language or the validity of the cross-linguistic correlation between the three telic constructions, this proposal reveals that a more detailed analysis of these constructions in Romanian requires a different and more careful approach, which also takes into consideration the source of the diachronic data. Put differently, although at first glance (Old) Romanian seems to be a counterexample to the generalization that connects the three constructions, especially as far as aspectual cognate constructions are concerned; on closer inspection, the data from the older stages of the language casts light on the fact that they are only apparent counterexamples, hence they do not challenge the validity of the above generalization.

The novelty value of the research summarized here is that it integrates aspectual cognate object constructions into the discussion on the above cross-linguistic correlation and proposes a unified analysis of the three telic constructions. Building on both my previous work and new research, I structure the paper in the following way. Section 2 presents the descriptive binary typology of satellite-framed and verb-framed languages (Talmy 1985, 1991, 2000), and the cross-linguistic correlation between the three constructions. Section 3 focuses on the modern Romanian data. Section 4 turns to Old Romanian and offers two possible solutions to the availability of the aspectual cognate constructions found in the texts belonging to this period. Section 5 concludes.

\section{Cross-linguistic correlation}

According to the literature (see Talmy 1972, 1975, 1985, 1991, 2000; Goldberg 1995; Levin \& Rappaport Hovav 1995; Snyder 2001; Beck \& Snyder 2001; Mateu 2002, 2012; Mateu \& Rigau 2002; Horrocks \& Stavrou 2003; McIntyre 2004; Zubizarreta \& Oh 2007; Acedo-Matellán 2010; Farkas 2013, a.o.), there is a conceptual similarity and cross-linguistic correlation between goal-of-motion (1) and so-called strong (Washio 1997) or true (Rapoport 1999) resultative constructions (2):

(1) a. The bottle floated into the cave.

b. The ballerinas danced into the room.

c. George swam to the shore.

a. John hammered the metal flat.

b. The professor talked his throat dry.

c. Mary danced her feet sore.

The first and best-known formalization of this correlation in the expression of motion is Talmy $(1972,1975,1985)$, who first proposed a typological classification of motion event constructions (see the examples in (1), which express literal motion from location $_{1}$ to location 2 ) and later extended it to other event constructions, particularly to resulting event constructions (see the examples in (2), which express metaphorical motion 
from state to $\mathrm{state}_{2}$ ). His analysis of - literal and metaphorical - motion is based on the following four semantic components: Figure (the entity that moves or undergoes change of state), Ground (the spatial reference point for the motion or change), Path/result (the element encoding the transition, i.e. the path of motion or the result of change) and Manner (the manner of motion by which the Figure moves along the path or the manner in which the result is brought about). Comparing the grammatical encoding of Manner and Path/result, Talmy developed a typology of how they are expressed depending on what incorporates them: the satellite or the verb. ${ }^{4}$ More precisely, the two constructions describing motion events are classified according to whether they lexicalize the Path/result in the satellite or in the verb, and, consequently, incorporate Manner in the verb or in the satellite/adjunct. As such, in so-called satellite-framed languages Path/result is lexicalized by the satellite (and Manner is incorporated in the verb); but in so-called verb-framed languages Path/result is incorporated in the verb (and Manner is or can be lexicalized outside the verb, for instance, in an adjunct). To put it differently, the possibility of lexicalizing Path/result in the satellite explains the availability of goal-of-motion and strong resultative constructions in satellite-framed languages. Conversely, the impossibility of lexicalizing Path/result in the satellite explains the unavailability of these two structures in verb-framed languages.

From this perspective, the goal-of-motion structure in (1a) is formed with an atelic manner-of-motion verb (float) and a satellite (i.e. the PP complement into the cave), which expresses Path and indicates the endpoint of motion. In such a case, the Manner-incorporating verb does not inherently encode directionality towards an end location. Similarly, the strong resultative construction in $(2 \mathrm{a})$ is formed with an atelic activity verb encoding Manner (hammer) and a satellite (i.e. the AP result predicate flat), which expresses end result. In such a case, the role of the result predicate is to add a piece of information that is not predictable from the basic sense of the verb as the result is not encoded in its meaning. In addition, the event expressed by the verb and the end state denoted by the result predicate are temporally independent of each other (cf. Rappaport Hovav \& Levin 2001).

More importantly, it has been observed in the literature (see, for instance, Massam 1990; Tenny 1994; Felser \& Wanner 2001; Horrocks \& Stavrou 2006, 2010; Real Puigdollers 2008 and Kitahara 2010) that there is a conceptual similarity and cross-linguistic correlation not only between goal-of-motion and strong resultative constructions but also albeit to a lesser degree - between these two telic structures and aspectual cognate object constructions. Although the Talmian typological classification of complex event constructions does not extend to aspectual cognate constructions per se, it has been argued that it is possible to make cross-linguistic generalizations about the (un)availability of these three (and also other) structures such that if the syntax of a language allows/disallows the formation of one of them, it also allows/disallows the formation of the other two. English falls into the former category as, besides goal-of-motion and strong resultative constructions, it also allows canonical aspectual cognate structures, as illustrated below:

\footnotetext{
${ }^{4}$ The satellite is generally considered an uninflected element such as a particle, a prefix or a preposition; it is the complement of the main verb and projects an independent functional phrase (e.g. PathP or resP).
} 
(3)
a. $\quad$ Mary smiled a wide smile.
b. The baby slept a sound sleep.
c. The old man laughed an uproarious laugh.

As opposed to a transitive cognate construction built on a prototypical transitive verb (such as to do in a VP like to do deeds) or a transitivizing cognate structure built on a so-called derived unergative verb (such as to dance in a VP like to dance a dance), an aspectual cognate object structure is built on a so-called prototypical unergative verb such as to smile, to sleep or to laugh (see above). This is followed by a (modified) DP cognate object, which is both semantically and morphologically related to the verb. Crucially, the aspectual cognate nominal cannot be treated as a referential, thematic or subcategorized object. Hence, it fails the tests of passivization (e.g. *A sound sleep was slept by the baby.), it-pronominalization (e.g. *The baby slept it.), wh-questioning (e.g. *What did the baby sleep? A sound sleep.) and quantification with a strong determiner (e.g. *The baby slept this/each/most/every sound sleep.); cf. Jones (1988), Moltmann (1989), Massam (1990), Horita (1996), Kuno \& Takami (2004), de Swart (2007) or Real Puigdollers (2008), among many others. Moreover, the main function of the entire construction is the expression of a limited event with beginning and end, hence the term 'aspectual' (see Horrocks \& Stavrou 2010 or Lavidas 2013a, 2013b, 2014, 2018).

In all three telic constructions, it is the sentence-final satellite - i.e. the PP Path complement, the AP result predicate and the aspectual DP cognate object - that has an aspectual role in the structure and turns the atelic verb into a telic VP as the three constructions can felicitously be accompanied by the in-time adverbial:

(4) a. The bottle floated into the cave in ten minutes.

b. John hammered the metal flat in two hours.

c. $\quad$ ?Mary smiled a wide smile in two seconds. ${ }^{5}$

The generalization is that in satellite-framed languages, where Path/result is expressed by the satellite, all these constructions should equally be available and, conversely, in verb-framed languages, where Path/result is not encoded in the satellite, all three constructions should be unavailable. As English is a canonical example of a satellite-framed language, these constructions are available and productive, as shown above. However, as Romanian is a classic example of a verb-framed language, these constructions are expected to be unavailable.

With this cross-linguistic correlation in mind, I take a close look at this Romance language. In the course of my analysis, I uncover and discuss several apparent synchronic and diachronic counterexamples, and show that they do not ultimately represent real

\footnotetext{
${ }^{5}$ An important caveat is in order here: it has been noted in the literature that the aspectual cognate object effects a shift of aspectual character with respect to the corresponding atelic/unergative verb used on its own but the VP is not completely acceptable with the in-time adverbial (more precisely, it can take both the in-time and the for-time adverbial); see Tenny (1994), Levin \& Rappaport Hovav (1995), de Swart (2007), Real Puigdollers (2008), Horrocks and Stavrou (2010) or Melloni \& Masini (2017). In other words, the telic nature of the construction does not follow unequivocally from this canonical aspectual test. Instead, there are other tests that confirm the telicity of the VP.
} 
arguments against the prediction concerning the unavailability of these telic constructions in the language. More importantly, the availability of aspectual cognate constructions in Old Romanian does not point to the satellite-framed properties of this stage of the language but it can be explained by the fact that they are literal translations of the corresponding structures occurring in the original Slavonic and Greek/Hebrew documents and reflect the translator's great fidelity to the source text.

\section{The Romanian data}

According to the Talmian typology (cf. Talmy 1985, 1991, 2000), Romance languages including Romanian are canonical examples of verb-framed languages, which are hence predicted to lack both goal-of-motion and strong resultative constructions (see also Snyder 2001, Drăgan 2012, Farkas 2013). In addition, but not less significantly, in view of the cross-linguistic correlation discussed in this paper, Romanian should lack aspectual cognate object constructions as well. This prediction is borne out, as demonstrated in this section, which focuses on goal-of-motion (section 3.1), strong resultative (section 3.2) and aspectual cognate object constructions (section 3.3) in modern Romanian.

\subsection{Goal-of-motion structures}

Goal-of-motion structures are expected to involve the verb-framed pattern in Romanian. To put it differently, the language allows the lexicalization pattern where Path is incorporated in the motion verb and Manner can be lexicalized by an (optional) adjunct. ${ }^{6}$ These are the so-called verbs of inherently directed motion, which can appear in a configuration such as:
a. Sticla a intrat în peşteră (plutind).
bottle-the has entered in cave floating
'The bottle got into the cave (floating).'
b. Dansatoarele au ajuns la fereastră (valsând). dancers -the have arrived at window waltzing 'The dancers got to the window (waltzing).'
c. Soldaţii au intrat în oraş (mărşăluind). soldiers-the have entered in town marching 'The soldiers entered the town (marching).'

\footnotetext{
${ }^{6}$ Notice that the Path verb + locative PP combination is the lexicalization pattern favoured in Romanian (and more generally in Romance languages) to express motion events but it is not a (goal) construction per se (see (5)). It hence differs from the Manner verb + Path PP pattern, which is both a (goal) construction and the lexicalization pattern favoured in English (and more generally in Germanic languages) to express motion events, and whose telic change-of-location meaning is compositionally derived in syntax (see (1)).
} 
These examples show that in Romanian it is only with Path-incorporating verbs that a directed-motion reading is derived in the company of a morphologically simple $\mathrm{P}$ such as $\hat{i n}$ 'in' (see (5a) and (5c)) or la 'at' (see (5b)). In addition, the postverbal locative PPs lexicalize the end location or the final destination of the path-incorporating motion (they can be considered to be part of a complex Path + Place PP selected by the verb, of which only the latter is lexicalized).

Other verbs of inherently directed motion are $a$ cădea 'to fall', a coborî̀ 'to climb down', a se duce 'to go', a ieşi 'to go out/exit', a înainta 'to advance', a se înălţa 'to rise', a se intoarce 'to come back', a pleca 'to leave', a reveni 'to return', a sosi 'to arrive', a se sui 'to ascend', a se urca 'to climb up' or a veni 'to come'. Most of these verbs describe telic events; hence, they can derive directed-motion VPs even when they are accompanied by a PP headed by a morphologically simple preposition.

Crucially, the following sentences built on the satellite-framed pattern can only have an atelic locative interpretation (i.e. 'the bottle floated in the cave') but not a telic directional reading (i.e. 'the bottle floated into the cave'), which leads us to the generalization that Romanian manner-of-motion verbs fail to derive telic, directed-motion structures with morphologically simple prepositions. This is because Romanian Ps such as $\hat{i n}$ 'in', la 'at', sub 'under' or pe 'on' are locative and there are no accomplishment prepositions comparable to the English to, into or onto.
a. *Sticla a plutit în peşteră.
bottle-the has floated in cave
'The bottle floated into the cave.'
b. *Dansatoarele au valsat la geam.
dancers-the have waltzed at window
'The dancers waltzed to the window.'
c. *Soldaţii au mărşăluit în oraş.
soldiers have marched in town
'The soldiers marched into the town.'

Interestingly, when such an unergative manner-of-motion verb combines with a PP introduced by the PathP până 'as far as/up to/until' and a morphologically simple preposition, there seems to be a striking surface similarity between this morphologically complex preposition and the English PP introduced by to/into/onto, and the entire structure seems to present satellite-framed behaviour (see Beavers et al. 2010 and others):

Sticla a plutit până în peşteră.

bottle-the has floated up to in cave

'The bottle floated up to the cave/until it ended up in the cave.'

The specificity of these PPs is that the Romanian până 'as far as/up to/until', similarly to the English -to, measures out the path involved in the event of (literal or metaphorical) motion, and $\hat{\imath} n$ 'in' or $l a$ 'at', similarly to in-/on-, indicate the endpoint of motion. However, the entire PP in such Romanian examples acts as an adjunct but the syntactic notion of Path that is relevant to Talmy's typology does not refer to phrases 
occupying an adjunct position but to phrases in a syntactic sisterhood relationship with the verb (see also Mateu 2012). Consequently, the până-counterpart of (6a), given in (7), does not turn Romanian into a satellite-framed language as it is only an apparent exception to the Talmian typological classification of this language, contra the claims made in Barbu (2015) ${ }^{7}$. In other words, such and similar examples are not counterexamples to the Talmian generalization, which predicts that in Romanian goal-of-motion structures the verb cannot conflate Manner and Motion, and Path cannot be lexicalized by the satellite (see also Farkas 2013).

Furthermore, Romanian allows a small set of verbs (such as a aluneca 'to slip/slide', a fugi 'to run', a păşi 'to step', a pătrunde 'to penetrate/go into', a se rostogoli 'to roll', a sări 'to jump', a se strecura 'to sneak' and a zbura 'to fly') to occur with a PP headed by a morphologically simple preposition and give rise to a telic directional interpretation. Again, VPs built on these verbs should not be taken as genuine counterexamples to Talmy's typology as such prepositions can only encode a locative rather than a directional meaning in Romanian. Hence, the directed-motion interpretation in the following examples is due precisely to the directional manner-of-motion verbs a se rostogoli 'to roll' (8a) and a se strecura 'to sneak' (8b), which differ from the non-directional (or pure) manner-of-motion verbs a pluti 'to float', a valsa 'to waltz', a se plimba 'to walk', a inota 'to swim' or a mărşălui 'to march' (see (5) and (6) above; see also Baciu (2006):
a.
Mingea s-
a
rostogolit în bazin.
ball-the REFL.3SG has rolled in pool
'The ball rolled into the pool.'
b. Un şoricel s- a strecurat în casă.
a mouse.DIM REFL.3SG has sneaked in houuse
'A little mouse sneaked into the house.'

What is interesting is that (8a) may have both a telic (goal-of-motion) and an atelic (manner-of-motion) interpretation as shown by its compatibility with the in-time (e.g. intr-o secundă 'in a second') and the for-time adverbial (e.g. timp de două minute 'for two minutes'). This, however, contrasts with VPs built on pure manner-of-motion verbs, which may only have an atelic reading with the same Place Ps (see Baciu 2006). Again, the telic interpretation in the former case can only be due to the properties of the verb and not those of the preposition, which can also appear in stative configurations with verbs such as a fi 'to be' or $a$ sta 'to stay'.

Also, transitive denominal verbs with the meaning 'to put in $\mathrm{N}$ ' - where $\mathrm{N}$ is the noun entering the word-formation process with the prefixes $\hat{\imath} n$-/îm-describe changes of location and derive telic constructions in combination with morphologically simple

\footnotetext{
${ }^{7}$ For a similar account of the Italian fino $a$ 'as far as/up to', the French jusqu'à 'as far as/up to/until' or the Spanish hasta 'as far as/up to', see Centineo (1986), Folli and Ramchand (2005), Zubizarreta and Oh (2007) or Bigolin \& Ausensi (in press), and the references cited therein. In a nutshell, in these languages the PP headed by the above prepositions is considered to be an adjunct and not a complement because it does not trigger change in the selected perfect auxiliary.
} 
prepositions. In the following example, the sentence-final PP specifies the end location of the change described by the verb:

(9) După condamnare, 1- au întemniţat la Rahova after conviction him have imprisoned at Rahova 'After the conviction, they imprisoned him at Rahova.'

Since the transitive denominal verb a intemniţa 'to imprison' independently denotes change in location, the above sentence is acceptable on a change-of-location reading but it is not built on the satellite-framed pattern.

In this subsection, I uncovered and discussed several motion examples, which proved to be only apparent counterexamples to the Talmian typology.

\subsection{Strong resultative constructions}

Romanian resultative constructions can only be built on verbs that independently encode result and the satellite (i.e. the result predicate) thus simply lexicalizes or specifies the result state, renders the vague endpoint of the event more precise or highlights the degree of the outcome of the event (see Farkas 2013). Consequently, the following sentences built on the satellite-framed pattern (i.e. an atelic Manner-incorporating verb combined with an AP result predicate) are all ungrammatical in the language, at least under a result interpretation:

$$
\begin{aligned}
& \text { *. } \quad \text { Ion a bătut/ ciocănit metalul plat. } \\
& \text { Ion has beaten hammered metal-the flat } \\
& \text { 'Ion beat/hammered the metal flat.' } \\
& \text { *Mama a gătit carnea uscată. } \\
& \text { mother has cooked meat-the dry } \\
& \text { 'Mother cooked the meat dry.' } \\
& \text { *Adam a băut ceainicul gol. } \\
& \text { 'Adam has drunk teapot-the empty } \\
& \text { 'Adam drank the teapot empty.' }
\end{aligned}
$$

Whereas the transitive (10a) and (10b) can have either a depictive reading (i.e. 'mother cooked the meat when the meat was dry') or an attributive interpretation (i.e. 'mother cooked the dry meat'); the intransitive (10c), where the verb does not independently subcategorize for the postverbal nominal ceainicul 'the teapot', is completely unacceptable in the language.

As illustrated below, Romanian allows only a small subclass of so-called weak (Washio 1997) or false/fake (Rapoport 1999) resultatives, where the verb entering the derivation independently entails result or at least encodes some directionality towards a result state, and the VP is telic even in the absence of the AP (11) or PP (12) satellite: 
(11) a. Copacii au crescut mari/înalţi.

trees-the have grown big tall

'The trees grew big/tall.'

b. Antonia şi- a tăiat părul scurt.

Antonia DAT.3SG has cut hair-the short

'Antonia cut her hair short.'

(12) a. Avionul s- a rupt în bucăţi. plane-the REFL.3SG has broken in pieces 'The plane broke into pieces.'

b. Maria a măcinat cafeaua (în) pudră.

Maria has ground coffee-the in powder

'Maria ground the coffee into powder.'

Such constructions are possible precisely because the inherently delimited verb is followed by a satellite that acts as a further specification of the result already inherent in the meaning of the verb (Tortora 1998) or adds a piece of information that is already predictable from the basic sense of the verb. In addition, the event expressed by the verb and the end state denoted by the result predicate are temporally dependent of each other (see Rappaport Hovav \& Levin 2001).

This generalization must be completed with the following caveat. As shown below, not all weak resultatives are possible in Romanian, as the following AP examples are either infelicitous under a result interpretation (see (13a) and (13b)) or have an ambiguous, resultative-non-resultative - that is, depictive and/or attributive - meaning $($ see $(13 \mathrm{c}))$ :
a. $\quad$ *Ion a spart vaza deschisă.
Ion has broken vase-the open
'Ion broke the vase open.'
b. *Lacul a îngheţat solid. lake-the has frozen solid
'The lake froze solid.'
c. ?Petru a vopsit gardul verde. Petru has painted fence-the green
'Petru painted the fence green.'

In such cases, although the verbs that enter the derivation independently incorporate Talmy's $(1985,1991,2000)$ result, entail change or at least encode some directionality towards a certain change, it is important to notice that Romanian is subject to severe constraints that further restrict the class of weak resultatives. More precisely, Romanian weak resultatives are restricted in the sense that the result predicate is preferably expressed by a PP (see (14)), which often reinforces the result interpretation as in (14b), a referential NP (see (15a)) or a predicative bare noun (see (15b)), see also Irimia (2013): 
(14)

a. Ion a spart vaza în bucăţi.

Ion has broken vase-the in pieces

'Ion broke the vase into pieces.'

b. Petru a vopsit gardul în verde.

Petru has painted fence-the in green

'Petru painted the fence green.'

(15)
a. Ion a spart geamul ţăndări.
Ion has broken window-the splinters
'Ion broke the window into splinters.'
b. Lacul a înghețat bocnă/tun.
lake-the has frozen bone cannon
'The lake froze as hard as a bone/cannon.'

The examples built on the verb a sparge 'to break' summarize the Romanian resultative pattern: whereas the result verb is infelicitous with an AP result predicate (e.g. deschisă 'open'), it is felicitous either with a PP predicate (e.g. în bucăţi 'into pieces') or a nominal predicate (e.g. ţăndări 'splinters'). However, the latter is the result of an elliptical PP as the presence of a modifier requires the PP variant (Drăgan 2005); see (16) below:

$$
\begin{aligned}
& \text { Ion a spart geamul *(în) mii de ţăndări. } \\
& \text { Ion has broken window-the in thousands of splinters } \\
& \text { 'Ion broke the window into thousands of splinters.' }
\end{aligned}
$$

Whereas the verb a sparge 'to break' can take the nominal predicate ţăndări 'splinters', the modified version of this predicate (e.g. mii de ţăndări 'thousands of splinters') obligatorily needs the preposition in 'in'.

Based on the evidence presented in this subsection, I conclude that Romanian fully conforms to the Talmian typological description of the language and its syntax uniformly precludes the formation of this metaphorical motion construction with the satellite-framed strategy.

\subsection{Aspectual cognate object constructions}

In conformity to the cross-linguistic correlation between the three telic constructions, Romanian is expected to block, besides goal-of-motion and strong resultative constructions, aspectual cognate object constructions as well. Indeed, these structures are known to be largely absent in modern Romanian as, with very few exceptions (see (17)), this language disallows the combination of a prototypical unergative verb with a (modified) cognate object, which is both semantically and morphologically related to the verb (see (18)); see also Dragomirescu $(2010,2013)$ or Dragomirescu \& Nicolae (2013):

a. Ion a muncit o muncă grea.

Ion has worked a work hard

'Ion worked hard.' 
b. Ea a tuşit o tuse seacă. she has coughed a cough dry 'She coughed a dry cough.'

c. Va lăcrima lacrimă de bucurie. will cry tear of happiness '(S)he will cry tears of happiness.'

(18) a. *Maria a dormit o dormire profundă.

Maria has slept a sleeping deep

'Maria slept a sound sleep.'

b. *Copilul a zâmbit un zâmbet larg. child-the has smiled a smile wide

'The child smiled a wide smile.'

c. *Emil a urlat un urlet de durere.

Emil has roared a roar of pain

'Emil roared a roar of pain.'

In this paper, as I take the terms "aspectual cognate object" and "aspectual cognate object construction" in the narrowest sense, I am primarily interested in those constructions where the prototypical unergative verb is followed by a DP/NP object, which is both semantically and morphologically related to the verb. As illustrated in (18) above, this pattern is largely absent in modern Romanian. Instead, as shown below, contemporary Romanian allows VPs where the object NP/DP is only semantically related to the prototypical unergative verb (19a), it is both semantically and morphologically related to the verb but it is nested into a PP (adjunct) (19b) or the verb is a light verb (19c):

a. Maria a dormit un somn profund.

Maria has slept a sleeping deep

'Mary slept a sound sleep.'

b. Copilul a zâmbit cu un zâmbet larg. child-the has smiled with a smile wide

'The child smiled with a wide smile.'

c. Emil a scos un urlet de durere.

Emil has taken out a roar of pain

'Emil roared with pain.'

Interestingly, prototypical unergative verbs can also appear in a pattern where a punctuation mark such as a colon (20a), a comma (20b) or a hyphen (20c) blocks or breaks the strict adjacency between the verb and the modified cognate nominal:

a. După care a zâmbit: un zâmbet larg after which has smiled a smile wide 'After which (s)he smiled: a wide smile' 
b. Cineva a ţipat, un ţipăt scurt, ca şi cum ... somebody has screamed a scream short as if 'Somebody screamed, a short scream, as if ...'

c. Nick a oftat - un oftat din acela prelung şi afectat Nick has sighed a sigh from that prolonged and affected 'Nick sighed - one of those prolonged and affected sighs'

(CoRoLa)

Although the nominals in the above examples are all derived from the root of the unergative verb, the punctuation marks indicate that the verb and the nominal are not syntactically related as they are not part of the same syntactic structure. Moreover, it is less clear whether the nominal is contained in the same clause that also contains the verb, as further sustained by the intonational break between these two elements.

These and similar examples (cf. both (19) and (20)) are not aspectual cognate object constructions in the narrowest sense of the word (see above) and, needless to say, they are not real counterexamples to the generalization that Romanian disallows aspectual cognate constructions as the availability of such and similar examples is not problematic in any of the verb-framed languages.

\subsection{Interim summary}

In this section of the paper, I demonstrated that contemporary Romanian lacks not only goal-of-motion and strong resultative structures but also aspectual cognate object constructions (in the sense defined here). This is not surprising, considering the Talmian typological classification of complex event constructions and the validity of the cross-linguistic correlation between the three structures, according to which the syntax of the verb-framed Romanian should preclude the formation of all three telic constructions. Crucially, they are not totally absent in the language but I have argued that such features do not call into question Talmy's typology since they are merely apparent counterexamples.

However, as shown in the next section, Old Romanian has a rich repertoire of aspectual cognate constructions but I argue that their availability does not automatically imply the availability of both goal-of-motion and strong resultative constructions in this stage of the language but these former structures are taken over literally from the original Slavonic and Greek/Hebrew documents, and reflect the translator's great fidelity to the source religious text (see also Nicula Paraschiv \& Niculescu 2016). Without questioning the typological classification of Romanian as a verb-framed language or the validity of the cross-linguistic correlation between the three telic constructions, this proposal reveals that a more detailed analysis of the aspectual cognate constructions in Romanian requires a different and more careful approach, which also takes into consideration the source of the diachronic data. 


\section{The Old Romanian data}

What is puzzling and challenging is that, in sharp contrast to modern Romanian, aspectual cognate object constructions are extremely frequent in Old Romanian (1521-1780), where they are used especially - but not exclusively - in religious texts; cf. Frâncu (2009), Dragomirescu (2010, 2013), Dragomirescu \& Nicolae (2013), Pană Dindelegan (2014, 2016), Nicula Paraschiv \& Niculescu (2016) or Farkas (in press). They can be built on a wide variety of unergative verbs such as: a alerga 'to run', a se bucura 'to rejoice', a boli 'to be ailing', a călători 'to travel', a se ciudi 'to be surprised', a cugeta 'to meditate', a dormita 'to sleep', a fulgera 'to lighten', a goni 'to race', a gurui 'to grunt', a leni 'to lazy', a lucra 'to work', a mănia 'to rage', a se mira 'to be surprised', a se mîhni 'to sadden', a odihni 'to rest', a se osteni 'to get tired', a osti 'to make war', a plinge 'to cry', a posti 'to fast', a se ruga 'to pray', a se scîrbi 'to be disgusted', a somna 'to sleep', a tîngui 'to weep', a unbla/umblalîmbla 'to walk', a se veseli 'to rejoice', a viteji 'to be brave' or a se zăbâvi/zăbovi 'to linger'. ${ }^{8}$ Some illustrative examples follow:

(21) a. bună oaste oştit- am şi cursura am curs good fight fought have and running have run 'I fought a good fight and finished my course'

b. iară somnul ce somnăm and sleep-the that sleep 'and the sleep that we sleep'

c. şi de odihna voastră, care odihneaţi and of rest your that rest 'and of your rest that you took'

d. veri să blastâmi lenea ta ce tei lenit will CONJ curse laziness your that REFL.2SG-have lazed 'you will curse the laziness that you lazed'

e. pentru bucuriia ce $\mathrm{s}-$ au bucuratu

$(\mathrm{CazV}, 100)$ for joy that REFL.3PL have rejoiced 'for the joy over which they rejoiced'

f. scîrba ce se- au scîrbit pre dînsul aversion that REFL.3PL have disgusted PE him 'the aversion that they felt towards him' 


$$
\begin{aligned}
& \text { g. au plîns plîngere mare foarte } \\
& \text { have wept weeping big very } \\
& \text { 'they wept very bitterly' }
\end{aligned}
$$

Moreover, a closer look at these constructions reveals that there is a slight variation between the two periods of Old Romanian: between 1521 and 1640 they are extremely frequent in diverse (but especially religious) texts, and between 1640 and 1780 they are less frequent or the two building blocks of the construction are slowly replaced by a synonym/hyponym or a light verb (see also Frâncu 2009). This is illustrated with the following pairs of examples taken from Biblia de la București (1688) and Biblia de la Blaj (1795); cf. also Farkas (in press):

$$
\begin{array}{lll}
\text { a. } & \text { jîrtvuiră } & \text { jîrtvă } \\
& \text { sacrificed } & \text { sacrifice }
\end{array}
$$

b. au adus jertvă

have brought sacrifice

'offered a sacrifice'

$$
\begin{array}{lll}
\text { a. } & \text { să ne îmbătăm beție } \\
& \text { SĂ REFL.1PL get drunk drunkenness } \\
\text { b. } & \text { să ne îmbătăm } \\
& \text { SĂ REFL.1PL get drunk } \\
& \text { 'we fill ourselves with strong drink' }
\end{array}
$$

In these pairs of examples, the introduction of a light verb (22) and the complete omission of the cognate nominal (23) aim to gradually reduce the redundancy between the verb and the cognate element (this change in the latter pair of examples should also take into account the original Greek texts on which the two translations are based; see Farkas in press).

Despite this variation between the two periods of Old Romanian, it remains to be seen how I can explain the availability and wide variety of aspectual cognate object constructions in the older stage of the language. In other words, the above-presented diachronic data poses serious challenges to my unified analysis of the three telic constructions. On the one hand, although Talmy's $(1972,1975,1985,1991,2000)$ typological classification of complex event constructions does not extend to aspectual cognate object constructions per se, in view of the cross-linguistic correlation between the three structures, the availability of these cognate constructions can point to the satellite-framed properties of this stage of the language, which would (or should) automatically imply the availability of both goal-of-motion and strong resultative constructions in Old Romanian. This should come as no surprise as it is argued that residues of the satellite-framed system involving the manner conflation mechanism are traceable more generally in Old Romance such as Old/Middle French and Old Catalan, which are hence considered not verb-framed 
but weak satellite-framed languages. On the other hand, the availability of aspectual cognate constructions found in Old Romanian can be explained by the fact that they are translated literally from the original Slavonic and Greek/Hebrew documents and reflect the translator's great fidelity to the source text (see also Nicula Paraschiv \& Niculescu 2016). In this section of the paper, in the absence of clear evidence to support the first approach (Section 4.1), I argue for the second approach (Section 4.2), which is also independently corroborated and encouraged by other diachronic data.

\subsection{Old Romanian as a weak satellite-framed language}

Although the way languages express motion has been studied for several decades, in recent years more and more attention is devoted to changes in the encoding of motion events from a diachronic perspective since it has been noticed that languages tend to change from one prevalent framing type to another. In this sense, a closer look at Old Romance languages such as Old/Middle French and Old Catalan reveals that they present the satellite-framed pattern, with Latin being considered a so-called weak satellite-framed language; see Acedo-Matellán (2010, 2016), Acedo-Matellán \& Mateu (2013), Burnett \& Troberg (2014), Troberg \& Burnett (2017), and the references cited therein. This means that at this stage of these languages the Path and the verb are two different morphemes but form one phonological word (see also footnote 3). In the following Latin (24a), Medieval French (24b) and Old Catalan (24c) examples the verbal prefixes de-, ad- and $a$-, respectively, accompany a manner-of-motion verb (run, fly and walk, respectively), express directionality and form a directional telic VP:

a. Ad naves de- currunt.

at ships down run

'They run down towards the ships.'

(adapted from Acedo-Matellán 2016: 86)

b. l' innumerable nombre de langoustes qui ad volerent en France the innumerable number of locusts who to flew in France 'the uncountable number of locusts that flew into France'

(adapted from Troberg and Burnett 2017: 110)

c. Pot hom a-caminar sens peccat a guanyar perdonances can man to walk without sin to gain forgiveness 'One can go without sins to obtain forgiveness.'

(adapted from Acedo-Matellán and Mateu 2013: 256)

Moreover, Latin allows resultatives based on affixal particles (cf. (25a)) and Old French also allows AP resultatives which are not possible in Modern French (cf. (25b)):

(25) a. Serpentes ova solida hauriunt, [... ] atque putamina ex-tussiunt snakes egg whole swallow and shell out-cough 'Snakes swallow the eggs whole and expel the shells through coughing.' (adapted from Acedo-Matellán 2016: 112) 
b. Et le despoillirent tout nuz. and him plucked all naked 'And they plucked him completely naked.' (adapted from Burnett \& Troberg 2014: 45)

In a similar way, one could argue that the above aspectual cognate object data in Old Romanian points to the satellite-framed behaviour of this stage of the language as it is argued that residues of the satellite-framed system involving the manner conflation mechanism are traceable more generally in Old Romance (see Acedo-Matellán \& Mateu 2013). However, the claim that verbal prefixes in (some) Old Romance languages have an aspectual value and are able to change the aspectual properties of the predicate is based on French and Catalan texts dating from the $10^{\text {th }}-13^{\text {th }}$ century (Acedo-Matellán \& Mateu 2013). Moreover, Troberg \& Burnett's (2017) diachronic analysis of AP resultatives and verb particles emphasizes their simultaneous loss in the $16^{\text {th }}$ century of the French language. More precisely, although the data on French prepositions that encode Path meanings and give rise to a goal-of-motion interpretation is correlated with verb-particle and strong resultative constructions, Troberg \& Bernett (2017: 115) stress the idea that "this burst of innovation [...] does not appear to extend any later than the sixteenth century".

Crucially, Old Romanian refers to a period that starts in the early $16^{\text {th }}$ century (more precisely, 1521) and ranges to the late $18^{\text {th }}$ century (more precisely, 1780). The first original (i.e. non-translated) text to have survived in Romanian dates from 1521, and this letter (Scrisoarea lui Neacşu din Câmpulung) is only preceded by Psaltirea Hurmuzaki, which is known to have been copied around the year 1500 (see Timotin 2016: 1). Consequently, comparing the above Romance data and contrasting the periods that are relevant to the present discussion, I predict that residues of the satellite-framed system involving the manner conflation mechanism cannot and will not be traced in Old Romanian. This prediction is borne out, as shown and demonstrated below, where I focus neither on Old Romanian in its entirety (1521-1780) nor on the whole first period of Old Romanian (1521-1640) but only on the texts from the $16^{\text {th }}$ century $(1521-1600)$. The motivation behind this choice is that, according to my predictions, if residues of the satellite-framed system involving the manner conflation mechanism are traceable in Old Romanian, then they are (and should be) traceable, first and foremost, in the earliest texts, i.e. the ones from the $16^{\text {th }}$ and not the ones from the $17^{\text {th }}$ or $18^{\text {th }}$ centuries. In what follows, I summarize the key findings on goal-of-motion and strong resultative constructions in Old Romanian.

On the one hand, the motion verbs I have found in the few (original and translated) texts from the $16^{\text {th }}$ century are, first and foremost, directed motion verbs, which inherently include a specification of the direction of motion. In Talmy's (1985, 1991, 2000) terms, they incorporate Path and the PP headed by the morphologically simple preposition only specifies or lexicalizes the end location or final destination. Most of the examples found in my corpus are built on the following (mostly unaccusative) directed motion verbs: a ajunge 'to get/arrive', a cădea 'to fall', a (se) duce 'to go', a ieşi 'to go out/exit', a (se) intoarce 'to come back', a intra/întra 'to enter', a (se) muta 'to move', $a$ pica 'to fall', a pleca 'to go/leave', a sosi 'to arrive', a (se) sui 'to ascend', a (se) turna 'to come back/return' and $a$ veni 'to come'. This verb-framed pattern is already available 
in the oldest text written in Romanian (see (26a) below). Some further examples are illustrated in (26b)-(26h):

(26) a. şi se- au dus în sus pre Dunăre and REFL.3PL have gone in up on Danube 'and they went up on the Danube'

b. $\quad$ ajunsemu la cea adăpostitură bună arrived at that shelter good 'we arrived at that good shelter'

c. săpară între faţa mea groapă şi cădzură întru ea dug in face my hole and fell in it 'they dug up a hole in front of me and fell into in'

d. întraiu în casa ta entered in house your 'I entered your house'

e. în pământu se vor întoarce in ground REFL.3PL will return 'they will return to the ground'

f. astădzi sosiiu la fîntînă today arrived at fountain 'I arrived at the fountain today'

g. sui în ceriu ascended in heaven 'he ascended into heaven'

h. vine la puţ fără ruşine coms at well without shame 'he comes to the well with no shame'

The directed motion interpretation in all these examples is due to the verb inherently encoding directed motion.

In addition, there are some (mostly transitive) verbs which also inherently express motion from one location to another. Some of these verbs are: a aduce 'to bring', $a$ arunca 'to throw/drop', a băga 'to put', a impinge 'to push', a pune 'to put', a ridica 'to raise', a trage 'to pull' or a trimite 'to send'. By way of illustration, I give the following Old Romanian examples: 

a. Aşa Iosif fu aruncat în temniţă
like that Iosif was thrown in jail 'so Joseph was thrown into jail'
b. cela ce bagă apă în vin that who puts water in wine 'he who adds/pours water into wine'
c. să tragă pre ginerii- și în muncă SĂ pull PE sons-in-law-the DAT.3SG in work 'to force his sons-in-law into work'
d. tremease-i în toată lumea send to them in entire world 'he sent them into all the world'

Furthermore, Old Romanian allows directional manner-of-motion verbs to occur with a PP headed by a morphologically simple preposition such as $i n$ 'in' and generate a telic directional interpretation. Again, the directed-motion reading in the following examples is due to the verbs a fugi 'to run' (28a) and a se arunca 'to jump' (28b), which are not pure manner-of-motion verbs, and not to the PPs headed by in 'in':

$$
\begin{aligned}
& \text { a. Apoi ... au fugit în Ţara Muntenească } \\
& \text { then have run in Country Wallachian } \\
& \text { 'and then they ran into Wallachia' } \\
& \text { b. însă în deşertu se arruncă } \\
& \text { but in desert REFL.3SG throw } \\
& \text { 'but he jumps into the desert' }
\end{aligned}
$$

In addition, transitive denominal verbs with the meaning 'to put in $\mathrm{N}$ ' describe changes of location and derive telic constructions in combination with morphologically simple prepositions. In the following example, similarly to (9), the postverbal PP specifies the end location of the Path incorporated in the verb:

$$
\begin{aligned}
& \text { îngroapă mortul tău în mormîntul cel mai cinstit la noi } \\
& \text { bury deceased-the your in grave-the the most honest at us } \\
& \text { 'they bury your deceased in the most honest grave at us' }
\end{aligned}
$$

Although I have not found any verbal prefix that accompanies a manner-of-motion verb and expresses directionality in a telic VP, I have noticed that functional prepositions have a broader use in Old Romanian than in modern Romanian, some of them have 
special meanings specific to this period and fewer syntactic-semantic restrictions, and many of them are even in competition with each other (see also Frâncu 2009 or Nedelcu 2016). Related to this, two important caveats are in order here before proceeding any further. First, the complement of the preposition intru 'in' can be assigned the Goal theta role, as shown below, where the postverbal Goal PP is contrasted with the preverbal Source PP, hence the directional meaning of the former, which accompanies a pure manner-of-motion verb, is reinforced:

$$
\begin{aligned}
& \text { Deacolo înotară întru Antiohiă } \\
& \text { from there swam in Antioch } \\
& \text { 'from there they swam into Antioch' }
\end{aligned}
$$

Second, the motion verb a alerga 'to run' (see (31a)), as opposed to other non-directional (or pure) manner-of-motion verbs such as a imbla 'to walk' (see (31b)), can generate a directed-motion interpretation with a morphologically simple preposition:
a. şi cumu- i aud glasulu, ei aleargă la muma sa and as her hear voice they run at mother her 'and as they hear her voice, they run to her mother'

b. în casa Dzeului îmblăm cu gându in house of God walk with thought 'we walk in God's house with a thought'

As evidenced by (31a), the clause expressing motion in the sentence has a directed-motion and not a purely locative interpretation. This is in marked contrast to the observation made for (modern) Romanian concerning the difference between a fugi 'to run' and a alerga 'to run' in the expression of motion (see Baciu 2006, Farkas 2013).

On the other hand, the resultative constructions I have found in the $16^{\text {th }}$ century Old Romanian texts do not fall under the strong resultative pattern as in the few examples found in the Old Romanian texts the end state denoted by the predicate can generally be predicated by looking at the meaning of the result verb. The following AP (32) and PP (33) resultatives, similarly to the ones in (11) and (12), respectively, are all built on verbs that independently encode Talmy's $(1985,1991,2000)$ result and hence the predicates only lexicalize or further specify the result state. In addition, (32) is not a complex AP resultative and the examples in (33) are not PP resultatives headed by a prefixed verb, contra the PP resultatives found in a weak satellite-framed language (see above):

$$
\begin{aligned}
& \text { Nu- i duc la besearecă până nu cresc mari } \\
& \text { not them take at church until not grow big } \\
& \text { 'I will not take them to church until they have grown big' }
\end{aligned}
$$


a.

Ce pasările în doao nu taie what birds-the in two not cut 'What the birds do not cut into two'

b. să împarţă păcatele omului în 3 parţi SĂ divide sins-the men's in three parts 'so that he should divide men's sins into three parts'

$(\operatorname{PravL}, 165)$

c. Adunară iară într- o grămadă broaştele gathered again into a pile frogs-the 'he gathered the frogs into a pile again'

The verbs in these and similar PP constructions revolve around the concepts of 'separation' (see (33a) and (33b)) and 'gathering' (see (33c)), and both sets of examples are based on hyponymy; see also Drăgan (2005).

It is not unusual that, similarly to motion structures, PP resultatives are built with the morphologically complex preposition până $\hat{\imath} n / l a$ 'as far as/up to/until in/at'. One relevant example is given below:

$$
\begin{aligned}
& \text { până la sânge junghearei nevoiră- se } \\
& \text { until at blood stab needed REFL.3SG } \\
& \text { 'he needed to stab him to blood' }
\end{aligned}
$$

Such and similar examples, needless to say, do not turn (Old) Romanian into a (weak) satellite-framed language as building them is not problematic in any of the Romance languages. Although they have a result interpretation and the sentence-final PP expresses a delimitation (Barbu 2015), they are not resultative constructions per se. In addition, but not less significantly, such PPs are adjuncts but the syntactic notion of Path/result that is relevant to Talmy's typology does not refer to phrases occupying an adjunct position but to phrases in a syntactic sisterhood relationship with the verb (see also section 3.1).

Taking a close look at the above examples, I draw the conclusion that the first Romanian texts dating from the $16^{\text {th }}$ century do not show hallmarks of the satellite-framed pattern in the expression of motion or result constructions. Consequently, excluding the possibility of a satellite-framed subsystem within an otherwise verb-framed grammar, I must explain the availability and wide variety of aspectual cognate object constructions in Old Romanian from a different perspective. This is what I present in the next subsection.

\subsection{Old Romanian texts based on translation}

When discussing aspectual cognate constructions in Old Romanian and trying to integrate them into telic constructions more generally, one cannot disregard the fact that, with (very) few exceptions, most of the Old Romanian texts are based on translation. As 
such, in these (mostly religious) texts the cognate constructions reflect the influence of the source language, as they are copied from the original Slavonic documents, which, in turn, are taken over literally from the Greek and Hebrew versions of the texts (see Gamanovich 2001, Arvinte 2006, Pană Dindelegan 2016, Nicula Paraschiv \& Niculescu 2016). In addition, they are often associated with a stylistic choice and are claimed to have an emphatic function.

But it is equally true that the original (i.e. non-translated) and translated texts of this stage of the language influence each other, so that a phenomenon considered to be an imitation of a foreign model such as the cognate object construction occurs in original texts as well. Consequently, considering the presence of this foreign element in Romanian original texts, I am led to conclude, together with Pană Dindelegan \& Dragomirescu (2016: 635-637), that it consolidates a construction present in the grammar of Romanian, and it is not the result of a process of complete transfer of the corresponding foreign structure into the grammar of the language. ${ }^{9}$

That one of the hallmarks of Old Romanian is the wide variety of cognate constructions in both its original (religious, historical or literary) and translated texts is evidenced by the fact that it abounds not only in aspectual but also in transitive and transitivizing cognate constructions (built on prototypical transitive and derived unergative verbs, respectively). Some illustrative examples follow:

a. carele v- au făcut această mare facere de bine those to you have done this big deed of good 'those who did this good deed to you'

b. Să te întreb o întrebare

SĂ you ask a question

'so that I ask you a question'

c. sfatul care sfătuise cu dînşii advice-the that advise with them 'the advice he had given them'

d. aceasta iaste mărturia $\quad$ Zeului, ceaia mărturisi

(NÎnv, 156) this be confession-the God-of that confess 'this is God's confession that he made'

\footnotetext{
${ }^{9}$ An anonymous reviewer wonders whether the "imitation" proposal, argued for in the present paper, could face the following challenge: if the aspectual cognate construction already existed in the language at the time the translations were made (even if we lack data, there is reason to believe so on logical grounds), we could propose that the translators have found the construction ready to hand and used it. There are serious arguments against this possible proposal as it would fail to explain not only the stylistic distribution of these (and also other, that is, transitive and transitivizing cognate) structures but also the translator's great fidelity to the source text, which is imperative more generally in the case of religious but especially in the case of Biblical texts. Although in contemporary Romanian these constructions are not (very) rare in popular speech either (Dragomirescu 2010), they basically remain a literary figure referred to as figura etymologica.
} 
e. poruncă să- i poruncească

order SĂ to him order

'so that he gives him order'

f. greşalele ce greşescu ei noao

mistakes-the that err they to us

'the wrong they did us'

$\left(C I I^{2}, 108\right)$

g. darul ce te dăruiaşte

$\left(C C^{2}, 47\right)$

gift-the that you gift

'the gift that he gives to you'

$(F D, 172)$

Interestingly, even transitive and transitivizing cognate constructions are severely restricted in modern Romanian as the above examples all sound redundant and should therefore be rephrased, for instance, into a VP introduced by a light verb such as a avea 'to have', a da 'to give', a duce 'to take', a face 'to do/make' or a pune 'to put'. Instead, what is allowed in present-day Romanian is a small subclass of (mostly transitivizing) constructions based on a verb of (re-)creation (e.g. a cânta 'to sing', a construi 'to build', a dansa 'to dance', a desena 'to draw', a juca 'to play', a povesti 'to tell', a scrie 'to write', a visa 'to dream', a zidi 'to build') or consumption (e.g. a bea 'to drink', a mânca 'to eat').

In addition, Old Romanian is generally characterized by pleonastic structures, which all have a wider stylistic distribution. As shown by the following examples, semantic and morphological cognateness can also appear between the verb and the subject (36a), the nominal inside the PP adjunct (36b), the gerund (36c), the nominal comparative term (36d) or the modifier inside the DP object (36e). Furthermore, it is not unusual that there is only semantic cognateness between the two elements of the pleonastic structure (see (37) below); see also Bejan (1972), Pană Dindelegan (2014, 2016), Nicula Paraschiv \& Niculescu (2016):

(36) a. au strigatu strigătorii pace

have shouted heralds peace

'the heralds shouted peace'

$(C L M, 84)$

b. cu gilăluire nedereapta gilăluiră-me

with hatred unjust hated me

'they hated me with unjust hatred'

c. făcînd vei face şi putînd vei putea

$(P H, 107)$

doing will do and being able will be able

'thou shalt both do great things and also shalt still prevail'

$(B B .1688,217)$

d. ca uscăciune să uscară

as dryness SĂ dried

'it dried as dryness' 
e. şi am umblat pustietăţi neumblate and have walked deserts untracked 'we have gone through deserts, where there lay no way'

a.
pentru cea multă a Lui dragoste carea au
iubit pre noi
for the much of His love that have loved PE us 'for his great love wherewith he loved us'

$(B B .1688,884)$

b. Aceasta grăindu, glăsi

this uttering said

'Uttering this, he said'

$$
\left(C C^{2}, 351\right)
$$

This data leads to the observation that cognate and pleonastic structures more generally have a wider stylistic distribution (see Pană-Dindelegan 2016) and this overwrites the aspectual contribution of the cognate object and that of the entire aspectual cognate construction. In other words, the use and choice of these aspectual constructions is primarily motivated by stylistic choice and it reflects the translator's great fidelity to the source text.

\section{Conclusions}

In this paper, I discussed and analysed the cross-linguistic correlation between goal-of-motion, strong resultative and aspectual cognate object constructions, which are all expected to be unavailable in verb-framed languages such as Romanian. I uncovered and presented several instances which prove to be only apparent counterexamples to the three telic constructions, which do not call into question Talmy's $(1972,1975,1985$, 1991, 2000) typology and main descriptive generalization, and do not weaken the above correlation. As expected, modern Romanian lacks not only goal-of-motion and strong resultative constructions, but also aspectual cognate ones. Crucially, I argued that the availability and wide variety of aspectual cognate object constructions in Old Romanian does not point to the satellite-framed properties of this stage of the language but it should be explained by the fact that they are taken over literally from the original Slavonic and Greek/Hebrew documents, and reflect the translator's great fidelity to the source text. The present analysis thus sheds light on the necessity of a different and more careful approach to telic constructions in Romanian, which also takes into consideration the source of the diachronic data.

\section{Corpus}

ACP - Ivireanul, A. 1714. Capete de poruncă. In A. Ivireanul, Opere, edited by G. Ştrempel, 386-394. Bucharest: Minerva. 1972.

B.1795 - Biblia de la Blaj. Biblia, adecă Dumnezeiasca Scriptură a legii vechi şi a ceii noao, Blaj. 1795.

BB.1688 - Biblia de la București 1688. Biblia, adecă Dumnezeiasca Scriptură a Vechiului și Noului Testament. Bucharest: Editura Institutului Biblic. 1988. 
CazV-Varlaam. 1643. Cazania. In J. Byck (ed.). Bucharest: Editura Academiei. 1943.

$C B-1559-1560$. Codicele popii Bratul. In Al. Gafton (ed.). http://media.lit.uaic.ro/gafton.

$C C^{1}$ - Coresi. 1567. Tâlcul Evangheliilor. In Coresi, Tâlcul evangheliilor şi Molitevnic rumânesc, edited by V. Drimba, 31-187. Bucharest: Editura Academiei Române. 1998.

$C C^{2}$ - Coresi. 1581. Carte cu învătătură. In Diaconul Coresi, Carte cu învățătură (1581). Textul, edited by S. Puşcariu \& A. Procopovici. Bucharest: Sorec. 1914. Volumul 1.

CCat - Coresi. 1559. Catehism. In A. Roman-Moraru (ed.), Extras din volumul Texte româneşti din secolul al XVI-lea, 101-105. Bucharest: Editura Academiei Republicii Socialiste România. 1982.

$C I I^{2}$ - Cantemir, D. 1705. Istoria ieroglifică. In P. P. Panaitescu \& I. Verdeş (eds.), vol. II. Bucharest: Editura pentru literatură. 1965.

CLM - Costin, M. 1700-1750. Letopiseţul Ţării Moldovei. In M. Costin, Opere, edited by P. P. Panaitescu, 41-201. Bucharest: Editura de Stat pentru Literatură şi Artă. 1958.

CM - Coresi. 1567. Molitevnic rumânesc. In Coresi, Tâlcul evangheliilor şi Molitevnic rumânesc, edited by V. Drimba, 189-211. Bucharest: Editura Academiei Române. 1998.

CoRoLa - Corpus computaţional de referinţă pentru limba română contemporană. (https://corola.racai.ro/)

$D \hat{I}$ - Documente şi însemnări româneşti din secolul al XVI-lea. In G. Chivu, M. Georgescu, M. Ioniţă, Al Mareş and A. Roman-Moraru (eds.), 91-212. Bucharest: Editura Academiei Republicii Socialiste România. 1979.

DP - Dosoftei. 1680. Psaltirea de-nţăles. In M. Cobzaru (ed.), 273-704. Iaşi: Demiurg. 2007.

$F D$ - 1592-1604. Floarea darurilor. In A. Moraru (ed.), Cele mai vechi cărţi populare în literatura română I, 119-182. Bucharest: Editura Minerva. 1996.

GCond - Literatura românească de ceremonial. Condica lui Gheorgachi, 1762. In D. Simonescu (ed.), 262-312. Bucharest: Fundația Regele Carol I. 1939.

NÎnv - 1700. Învăţăturile lui Neagoe Basarab către fiul său Teodosie. In F. Moisil \& D. Zamfirescu (eds.), 125-352. Bucharest: Minerva. 1970.

PH - 1500-1510. Psaltirea Hurmuzaki. In I. Gheţie \& M. Teodorescu (eds.), 85-211. Bucharest: Editura Academiei Române. 2005.

PO - 1582. Palia de la Orăştie. In V. Pamfil (ed.). Bucharest: Editura Academiei Republicii Socialiste România. 1968.

PravîL - 1652. Indreptarea legii. In A. Rădulescu (ed.), 33-631. Bucharest: Editura Academiei Republicii Socialiste România. 1962.

PravL - 1652. Pravila ritorului Lucaci. In I. Rizescu (ed.), 161-183. Bucharest: Editura Academiei Republicii Socialiste România. 1971.

PS - 1573-1578. Psaltirea Scheiană. In I.-A. Candrea (ed.), Psaltirea Scheiană comparată cu celelalte psaltiri din sec. XVI şi XVII traduse din slavonă. Bucharest: Socec. 1916. Volumul II.

ŞT-1644. Şeapte taine a besearecii. In I. Mazilu (ed.), 173-259. Iaşi: Editura Universităţii „Alexandru Ioan Cuza". 2012.

VE - 1703. Viaţa lui Esop. In V. Barbu (ed.), 175-208. Bucharest: Minerva. 1999.

\section{References}

Acedo-Matellán, V. 2010. Argument Structure and the Syntax-Morphology Interface. A Case Study in Latin and Other Languages. PhD dissertation, Universitat Autònoma de Barcelona.

Acedo-Matellán, V. 2016. The Morphosyntax of Transitions. A Case Study in Latin and Other Languages. Oxford: Oxford University Press.

Acedo-Matellán, V. \& Mateu, J. 2013. Satellite-framed Latin vs. verb-framed Romance: A syntactic approach. Probus 25: 227-265.

Arvinte, V. 2006. Construcţii perifrastice în Biblia de la Bucureşti (1688), în ms. 45 și ms. 4389. In V. Arvinte (ed.), Studii de istorie a limbii române, 180-184. Iaşi: Editura Universităţii "Alexandru Ioan Cuza".

Baciu, I. 2006. Goal of motion constructions in English and Romanian. The case of 'a alerga' and 'a fugi'. Revue roumaine de linguistique LI (1): 43-54.

Barbu, A.-M. 2015. Diferenţa dintre limită şi ţintă exemplificată prin până (la) şi la, cu aplicaţie la analiza construcțiilor rezultative. Studii și cercetări lingvistice LXVI (1): 91-101.

Beavers, J., Levin, B. \& Tham, S. W. 2010. The typology of motion expressions revisited. Journal of Linguistics 46: 331-377. 
Beck, S. \& Snyder, W. 2001. Complex predicates and Goal PP's: Evidence for a semantic parameter. In A. H.-J. Do, L. Domínguez \& A. Johansen (eds.), Proceedings of the $25^{\text {th }}$ Annual Boston University Conference on Language Development, vol. I, 114-122. Somerville: Cascadilla Press.

Bejan, D. 1972. Relaţia internă frecventă în sintaxa limbii vechi. Studia Universitatis Babeş-Bolyai 1: 93-99.

Bigolin, A. \& Ausensi, J. in press. A new resultative construction in Spanish? A reply to Rodríguez Arrizabalaga. Folia Linguistica.

Burnett, H. \& Troberg, M. 2014. On the diachronic semantics of resultative constructions in French. In C. Piñón (ed.), Empirical Issues in Syntax and Semantics 10, 37-54. http://www.cssp.cnrs.fr/ eiss 10/eiss 10.pdf.

Centineo, G. 1986. A lexical theory of auxiliary selection in Italian. Davis Working Papers in Linguistics $1: 1-35$.

Dragomirescu, A. 2010. Ergativitatea: tipologie, sintaxă, semantică. Bucharest: Editura Universităţii din București.

Dragomirescu, A. 2013. Intransitive verbs. In G. Pană Dindelegan (ed.), The Grammar of Romanian, 72-82. Oxford: Oxford University Press.

Dragomirescu, A. \& Nicolae, A. 2013. L'objet interne en roumain: description, évolution et comparaison entre les langues romanes. In E. Casanova Herrero \& C. Calvo Rigual (eds.), Actas del XXVI Congreso Internacional de Lingüistica y de Filología Románicas, 147-158. Berlin: Walter de Gruyter. Volume II.

Drăgan, R. 2005. On resultative constructions and ÎN/IN (-EN) prepositions/prefixes in Romanian and English. In M. Burada (ed.), Conference on British and American Studies, 99-104. Braşov: Editura Universităţii Braşov.

Drăgan, R. 2012. Aspects of Lexical Structure: Verbs in Locative Constructions in English and Romanian. Bucureşti: Editura Universităţii din Bucureşti.

Farkas, I.-Á. 2013. Resultative Constructions in English and Romanian. A Comparative Analysis. Cluj-Napoca: Presa Universitară Clujeană.

Farkas, I.-Á. in press. Tradiţie şi inovaţie în Biblia de la Bucureşti (1688) şi Biblia de la Blaj (1795): Construcţii cu complement intern. Studii şi cercetări lingvistice LXXII.

Felser, C. \& Wanner, A. 2001. The syntax of cognate and other unselected objects. In N. Dehé \& A. Wanner (eds.), Structural aspects of semantically complex verbs, 105-130. Bern: Peter Lang.

Folli, R. \& Ramchand, G. 2005. Prepositions and results in Italian and English. An analysis from event decomposition. In H. Verkuyl, H. de Swart \& A. van Hout (eds.), Perspectives on Aspect, 81-105. Dordrecht: Springer.

Frâncu, C. 2009. Gramatica limbii române vechi (1521-1780). Iaşi: Demiurg.

Gamanovich, A. 2001. Grammar of the Church Slavonic Language. Jordanville, NY: Holy Trinity Monastery.

Goldberg, A. 1995. Constructions. A Construction Grammar Approach to Argument Structure. Chicago, IL: The University of Chicago Press.

Horita, Y. 1996. English cognate object constructions and their transitivity. English Linguistics 13: 221-247.

Horrocks, G. \& Stavrou, M. 2003. Actions and their results in Greek and English: The complementarity of morphologically encoded (viewpoint) aspect and syntactic resultative predication. Journal of Semantics 20: 297-327.

Horrocks, G. \& Stavrou, M. 2006. The role and status of cognate objects across languages. Paper presented at the 29th GLOW Colloquium of Generative Grammar. Universitat Autònoma de Barcelona, 6-8 April 2006.

Horrocks, G. \& Stavrou, M. 2010. Morphological aspect and the function and distribution of cognate objects across languages. In M. Rappaport Hovav, E. Doron \& I. Sichel (eds.), Lexical Semantics, Syntax, and Event Structure, 284-308. Oxford: Oxford University Press.

Irimia, M.-A. 2013. How to turn into a resultative. In S. Keine \& S. Sloggett (eds.), NELS 42: Proceedings of the 42nd Annual Meeting of the North East Linguistic Society, vol. I. 249-260. Amherts, University of Massachusetts: GLSA.

Jones, M. A. 1988. Cognate objects and the Case-filter. Journal of Linguistics 24: 89-110.

Kitahara, K. 2010. English Cognate Object Constructions and Related Phenomena: A Lexical-Constructional Approach. PhD dissertation, University of Tsukuba.

Kuno, S. \& Takami, K. 2004. Functional Constraints in Grammar. On the Unergative-Unaccusative Distinction. Amsterdam/Philadelphia: John Benjamins. 
Lavidas, N. 2013a. Null and cognate objects and changes in (in)transitivity. Evidence from the history of English. Acta Linguistica Hungarica 60: 69-106.

Lavidas, N. 2013b. Unaccusativity and the diachrony of null and cognate objects in Greek. In E. van Gelderen, M. Cennamo \& J. Barðdal (eds.), Argument Structure in Flux. The Naples-Capri Papers, 307-341. Amsterdam/Philadelphia: John Benjamins.

Lavidas, N. 2014. Cognate arguments and the transitivity requirement in the history of English. Lingua Posnaniensis LVI: 41-59.

Lavidas, N. 2018. Cognate noun constructions in Early Modern English. The case of Tyndale's New Testament. In H. Cuyckens, H. De Smet, L. Heyvaert \& C. Maekelberghe (eds.), Explorations in English Historical Syntax, 51-76. Amsterdam/Philadelphia: John Benjamins.

Levin, B. \& Rappaport Hovav, M. 1995. Unaccusativity. At the Syntax-Lexical Semantics Interface. Cambridge, MA: MIT Press.

Massam, D. 1990. Cognate objects as thematic objects. Canadian Journal of Linguistics 35: 161-190.

Mateu, J. 2002. Argument Structure: Relational Construal at the Syntax-Semantics Interface. PhD dissertation, Universitat Autònoma de Barcelona.

Mateu, J. 2012. Conflation and incorporation processes in resultative constructions. In V. Demonte \& L. McNally (eds.), Telicity, Change, and State: A Cross-Categorial View of Event Structure, 252-278. Oxford: Oxford University Press.

Mateu, J. \& Rigau, G. 2002. A minimalist account of conflation processes: Parametric variation at the lexicon-syntax interface. In A. Alexiadou (ed.), Theoretical Approaches to Universals, 211-236. Amsterdam/Philadelphia: John Benjamins.

McIntyre, A. 2004. Event paths, conflation, argument structure and VP shells. Linguistics 42: 523-571.

Melloni, C. \& Masini, F. 2017. Cognate constructions in Italian and beyond. In L. Hellan, A. Malchukov \& M. Cennamo (eds.), Contrastive Studies in Verbal Valency, 219-250. Amsterdam/Philadelphia: John Benjamins.

Moltmann, F. 1989. Nominal and clausal event predicates. In C. Wiltshire, R. Graczyk \& B. Music (eds.), Papers from the 25th Annual Regional Meeting of the Chicago Linguistic Society, 300-314. Chicago: Chicago Linguistic Society.

Nedelcu, I. 2016. Prepositions and prepositional phrases. In G. Pană Dindelegan (ed.), The Syntax of Old Romanian, 424-443. Oxford: Oxford University Press.

Nicula Paraschiv, I. \& Niculescu, D. 2016. Cognate objects and other pleonastic constructions. In G. Pană Dindelegan (ed.), The Syntax of Old Romanian, 605-611. Oxford: Oxford University Press.

Pană Dindelegan, G. 2014. Direct and secondary object ditransitive structures in Old Romanian. Linguistica Atlantica 33: 25-37.

Pană Dindelegan, G. 2016. The secondary direct object. In G. Pană Dindelegan (ed.), The Syntax of Old Romanian, 143-149. Oxford: Oxford University Press.

Pană Dindelegan, G. \& Dragomirescu, A. 2016. Conclusions. In G. Pană Dindelegan (ed.), The Syntax of Old Romanian, 629-637. Oxford: Oxford University Press.

Real Puigdollers, C. 2008. The nature of cognate objects. A syntactic approach. In S. Blaho, C. Constantinescu \& B. La Bruyn (eds.), Proceedings of ConSOLE XVI, 157-178. Leiden: Student Organization of Linguistics in Europe.

Rapoport, T. R. 1999. Structure, aspect, and the predicate. Language 75: 653-677.

Rappaport Hovav, M. \& Levin, B. 2001. An event structure account of English resultatives. Language 77: 766-797.

Snyder, W. 2001. On the nature of syntactic variation: Evidence from complex predicates and complex word-formation. Language 77: 324-342.

Son, M. 2009. Linguistic variation and lexical parameter: The case of directed motion. University of Pennsylvania Working Papers in Linguistics 15: 212-222.

Son, M. \& Svenonius, P. 2008. Microparameters of cross-linguistic variation: Directed motion and resultatives. In N. Abner \& J. Bishop (eds.), Proceedings of the 27th West Coast Conference on Formal Linguistics, 388-396. Somerville: Cascadilla Proceedings Project.

de Swart, P. 2007. Cross-linguistic Variation in Object Marking. PhD dissertation, LOT.

Talmy, L. 1972. Semantic structures in English and Atsugewi. PhD dissertation, University of California.

Talmy, L. 1975. Semantics and syntax of motion. In J. Kimball (ed.), Syntax and Semantics, vol. 4, 181-238. New York: Academic Press. 
Talmy, L. 1985. Lexicalization patterns: Semantic structure in lexical forms. In T. Shopen (ed.), Language Typology and Syntactic Description, vol. 3, 57-149. Cambridge: Cambridge University Press.

Talmy, L. 1991. Path to realization: A typology of event conflation. In L. A. Sutton, C. Johnson \& R. Shields (eds.), Proceedings of the Seventeenth Annual Meeting of the Berkeley Linguistics Society, 480-519. Berkeley: Berkeley Linguistics Society.

Talmy, L. 2000. Toward a Cognitive Semantics, vol. II. Cambridge, MA: MIT Press.

Tenny, C. 1994. Aspectual Roles and the Syntax-Semantics Interface. Dordrecht: Kluwer.

Timotin, E. 2016. Introduction. Presenting the corpus: Typologizing, dating, and locating the texts. In G. Pană Dindelegan (ed.), The Syntax of Old Romanian, 1-7. Oxford: Oxford University Press.

Tortora, C. 1998. Verbs of inherently directed motion are compatible with resultative phrases. Linguistic Inquiry 29: 338-345.

Troberg, M. \& Burnett, H. 2017. From Latin to Modern French: A punctuated shift. In É. Mathieu \& R. Truswell (eds.), Micro-change and Macro-change in Diachronic Syntax, 104-124. Oxford: Oxford University Press.

Washio, R. 1997. Resultatives, compositionality and language variation. Journal of East Asian Linguistics 6: 1-49.

Zubizarreta, M. L. \& Oh, E. 2007. On the Syntactic Composition of Manner and Motion. Cambridge, MA: MIT Press. 